\title{
Lipid Profile, Antidiabetic and Antioxidant Activity of Acacia ataxacantha Bark Extract in Streptozotocin- Induced Diabetic Rats
}

\author{
Rotimi O. Arise, Aderounmu I. Ganiyu and \\ Oluwafemi O. Oguntibeju
}

Additional information is available at the end of the chapter

http://dx.doi.org/10.5772/57151

\section{Introduction}

Diabetes mellitus is a heterogeneous primary disorder of carbohydrate metabolism which exists everywhere in the world and interests approximately 371 million people worldwide. The prevalence of diabetes mellitus is increasing with ageing of the population and lifestyle changes associated with rapid urbanization and westernization. The disease is found in all parts of the world and is rapidly increasing in its coverage [1,2]. WHO projects that diabetes will be the $7^{\text {th }}$ leading cause of death in $2030[2,3]$. It is a metabolic disorder initially characterized by a loss of glucose homeostasis with disturbances of carbohydrate, fat and protein metabolism resulting from defects in insulin secretion, insulin action, or both [4]. Without enough insulin, the cells of the body cannot absorb sufficient glucose from the blood; hence blood glucose levels increase, which is termed as hyperglycemia. If the glucose level in the blood remains high over a long period of time, this can result in long-term damage to organs, such as the kidneys, liver, eyes, nerves, heart and blood vessels. Complications in some of these organs can lead to death [5]

The roles of certain organs such as the pancreas, liver and kidney in diabetes mellitus are very important.The pancreas plays a primary role in the metabolism of glucose by secreting the hormones insulin and glucagon (Figure 1). The islets of Langerhans secrete insulin and glucagon directly into the blood. Insulin is a protein that is essential for proper regulation of glucose and for maintenance of proper blood glucose levels [6]. Glucagon is a hormone that opposes the action of insulin. It is secreted when blood glucose level falls. It increases blood glucose concentration partly by breaking down stored glycogen in the liver by a pathway 
known as glycogenolysis. Gluconeogenesis is the production of glucose in the liver from noncarbohydrate precursors such as glycogenic amino acids [7].

WHO classification of diabetes introduced in 1980 and revised in 1985 was based on clinical characteristics. The two most common types of diabetes were insulin-dependent diabetes mellitus (IDDM) or (type I) and non-insulin-dependent diabetes mellitus (NIDDM) or (type II). WHO classification also recognized malnutrition-related diabetes mellitus and gestational diabetes. Malnutrition-related diabetes was omitted from the new classification because its etiology is uncertain, and it is unclear whether it is a separate type of diabetes [8, 9, and 10].

International Diabetes Federation [11] reported that one in 10 adults will have diabetes by 2030, posing a huge challenge to health care systems around the world. According to the report, the number of people living with diabetes worldwide will increase to 552 million by 2030 from 366 million in 2011 unless action is taken. Over 80 percent of its related deaths occur in lowand middle-income countries. It has been predicted that the number of cases may jump by 90 percent even in Africa, where infectious diseases have previously been the top killer [11].

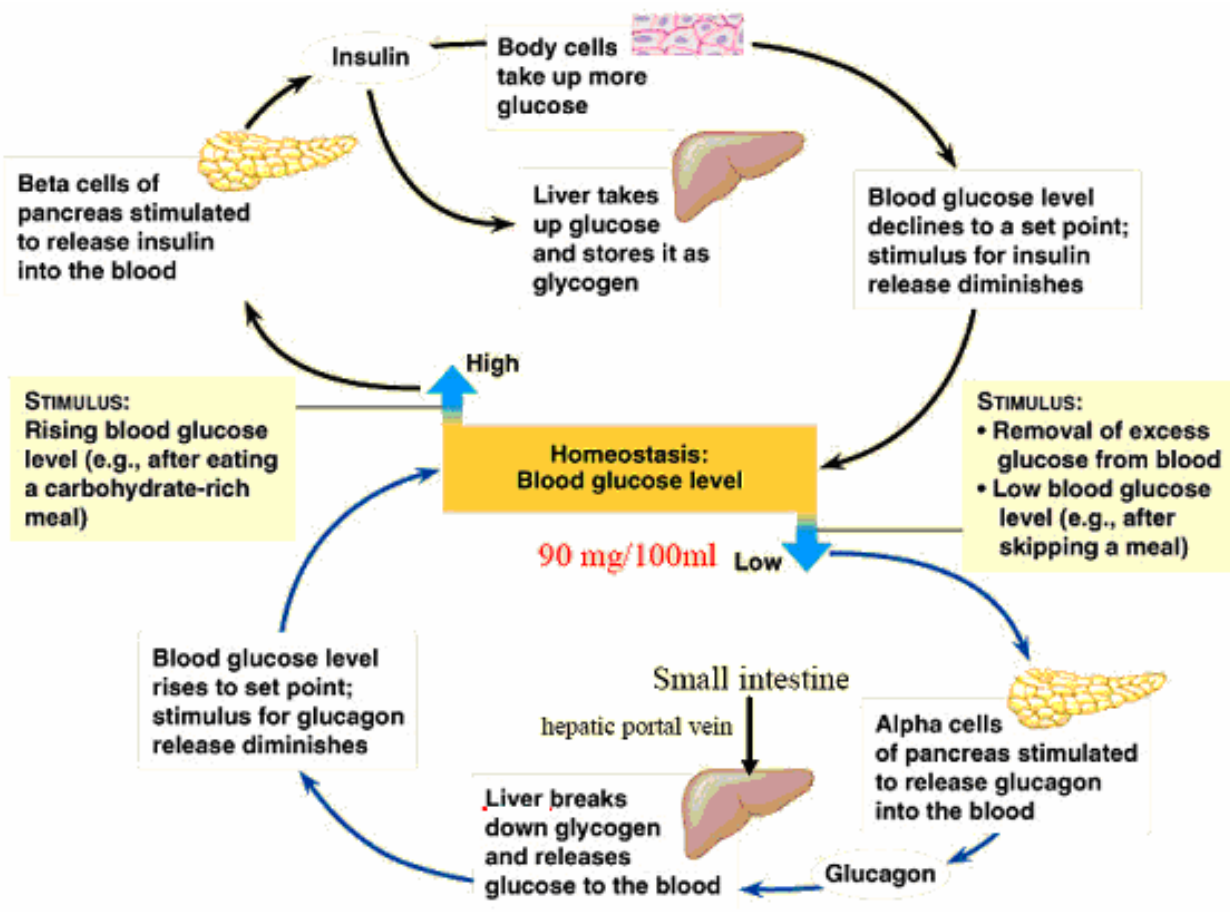

$\overline{\text { Source: Worthley }}[6]$

Figure 1. The role of pancreas in the body 
The conventional treatment for diabetes mellitus is oral hypoglycemic agents/insulin therapy [12]. However these have been shown to have prominent side effects and they do not modify the course of diabetic complications $[13,14]$. The need to develop new antidiabetic drugs has led to studies that have attempted to screen some indigenous plants for antidiabetic activity $[15,16]$. Traditional preparations of plant sources are widely used almost everywhere in the world to treat this disease. Therefore plant materials are considered to be the alternative sources for finding out new leads for antihyperglycemic agents. The plant drugs are frequently considered to be less toxic when compared to synthetic drugs [17]. More than 1,123 plant species have been used to treat diabetes and more than 200 pure compounds have been shown to possess characteristics of lowering blood glucose activity [18]. Acacia ataxacantha or Flame Thorn is an African tree species with conspicuous red pods and numerous hooked prickles. It is widespread in sub-Saharan Africa from Senegal in the west to Sudan in the east, Namibia, Botswana, Zimbabwe, and in the Transvaal and KwaZulu-Natal. In arid regions it prefers low-lying sites near streams, water courses and in valleys, but in higher rainfall areas it is a common member of the vegetation, often favouring forest margins. The flaking bark is light grey, splitting longitudinally and transversely, and revealing a buff under-colour. The persistent prickles are profuse on young twigs, but can also be found on older wood. Unlike most Acacias, the prickles are not in pairs, but scattered along young twigs ('ataxacantha' i.e orderless prickles).

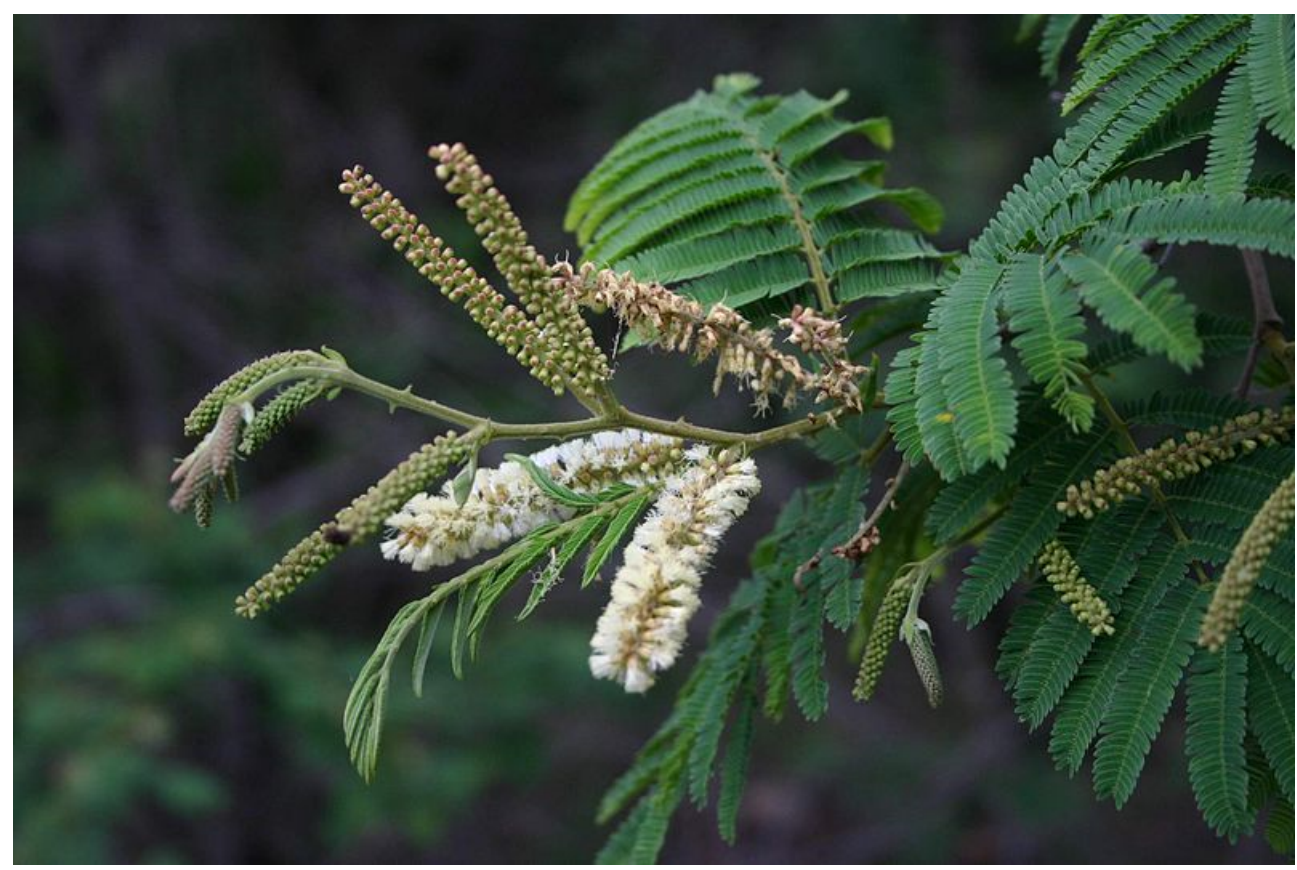

$\overline{\text { Source : Davidson }}$ and Jeppe [19]

Figure 2. Acacia ataxacantha 
Hence, the aim of this study is to investigate the anti-diabetic potential and safety evaluation of ethanolic extract of Acacia ataxacantha bark in streptozotocin-induced diabetic rats. The results were compared with standard anti-diabetic drug, metformin.

\section{Materials and methods}

\subsection{Experimental animals and reagents}

36 Albino rats (Rattus norvegicus) with an average weight of $132.5 \mathrm{~g}$ were obtained from the Animal Holding Unit of the Department of Biochemistry, University of Ilorin, Ilorin, Kwara State, Nigeria. Animal husbandry and experimentation were consistent with Guiding Principles in the use of Animals in Toxicology [20]. All the reagents used for this study were of analytical grade and were prepared in all glass-distilled water.

\subsection{Plant extract preparation}

The bark of Acacia ataxacantha was obtained from Akure, Ondo State, Nigeria. Identification was carried out at the University Ilorin Herbarium, Department of Plant Biology, Ilorin, Nigeria where voucher number 872 was deposited. The bark was air-dried under shade and pulverized into fine powder. $200 \mathrm{~g}$ of the fine powder was percolated in $500 \mathrm{ml}$ of absolute ethanol $\left(60-80{ }^{\circ} \mathrm{C}\right)$ for $24 \mathrm{~h}$. The percolated mixture was filtered and evaporated at room temperature according to the method of Majekodunmi et al. [21]. A homogenous aqueous suspension of the extract was made before administration to the experimental animals [21].

\subsection{Induction of experimental diabetes}

The animals were fasted overnight and diabetes was induced by a single intra-peritoneal injection of freshly-prepared STZ ( $55 \mathrm{mg} / \mathrm{kg}$ body weight of rats) in $0.1 \mathrm{M}$ citrate buffer ( $\mathrm{pH}$ 4.5) [22]. The animals were allowed to drink $5 \%$ glucose solution overnight to overcome the drug-induced hypoglycaemia. Control rats were injected with citrate buffer alone. The animals were considered as diabetic, if their blood glucose values were above $250 \mathrm{mg} / \mathrm{dL}$ on the third day after the STZ injection. The treatment was started on the fourth day after the STZ injection and this was considered the first day of treatment.

\subsection{Animals grouping}

All rats were maintained under standard laboratory conditions ( $12 \mathrm{~h} \mathrm{light/dark}$ cycle, $25 \pm 2$ $\left.{ }^{\circ} \mathrm{C}\right)$. The rats were acclimatized for a week in the laboratory. They were fed with standard rodent diet and tap water ad libitum. The animals were then randomly divided into 6 groups-

Group 1: Received distilled water (Control)

Group 2: Diabetic untreated rats

Group 3: Diabetic and treated with $125 \mathrm{mg} / \mathrm{kg}$ b.w of ethanolic extract of Acacia ataxacantha bark 
Group 4: Diabetic and treated with $250 \mathrm{mg} / \mathrm{kg}$ b.w of ethanolic extract of Acacia ataxacantha bark.

Group 5: Diabetic and treated with $500 \mathrm{mg} / \mathrm{kg}$ b.w of ethanolic extract of Acacia ataxacantha bark Group 6: Diabetic and treated with standard drug (Metformin)

\subsection{Sample preparation}

At the end of the experimental period, venous blood was collected from the experimental animals and serum was prepared by centrifuging the blood samples at $3000 \mathrm{rpm}$ for 5 minutes [23] and serum collected by pippeting. The animals were thereafter quickly dissected and the liver and pancreas removed. The pancreas and liver were suspended in ice-cold $0.25 \mathrm{M}$ sucrose solution $(1: 5 \mathrm{w} / \mathrm{v})$ and homogenized. The homogenates were kept frozen overnight to ensure maximum release of enzymes [24].

\subsection{Estimation of hepatic glucose and glycogen}

Hepatic glucose and glycogen were estimated using the method of Barham and Trinder [25] and Passoneau and Lauderdale [26] respectively.

\subsection{Determination of liver enzyme activities}

The method described by Reitman and Frankel [27] was used for assaying the activity of alanine aminotransferase and aspartate aminotransferase.

\subsection{Lipids profile analysis}

Total cholesterol, triglyceride, high density lipoprotein cholesterol, low density lipoprotein cholesterol were assayed using the method of Zlakis et al. [28], Foster and Dunn [29], Burstein et al.[30] and Friedwald et al. [31] respectively.

\subsection{Determination of liver function indices}

The procedure described by Doumas et al. [32] and Sherlock [33] was used for the determination of albumin and bilirubin concentrations respectively.

The method of Tietz et al. [34] was used to determine the levels of serum urea and creatinine.

\subsection{Determination of superoxide dismutase activity and malondialdehyde concentration}

The pancreatic superoxide dismutase activity was determined by the method of Misra and Fridovich [35] while malondialdehyde concentration was assayed using the method described by Varshney and Kale [36].

\subsection{Statistical analysis}

All data are expressed as the mean of sixth replicates \pm standard error of mean (S.E.M). Statistical evaluation of data was performed by SPSS version 16 using one way analysis of 
variance (ANOVA), followed by Dunett's posthoc test for multiple comparism. Values were considered statistically significant at $\mathrm{p}<0.05$ (confidence level $=95 \%$ ).

\section{Results}

\subsection{Phytochemical constituents of ethanolic extract of Acacia ataxacantha bark}

Table 1 shows the phytochemical constituents of ethanolic extract of Acacia ataxacantha bark. In the analysis carried out, alkaloids, polyphenols, flavonoids, saponins, tannins, terpernoids were present while glycoside was not detected.

\subsection{Glycemic effects of ethanolic extract of Acacia ataxacantha bark in streptozotocin- induced diabetic rats}

Figure 3 presents the glycemic effects of ethanolic extract of Acacia ataxacantha bark in streptozotocin-induced diabetic rats. There was continuous increase in the fasting blood glucose level of diabetic control rats from the first day of treatment till the sixth day. While, upon oral administration of ethanolic extract of Acacia ataxacantha bark, there was a significant reduction $(\mathrm{p}<0.05)$ in the fasting blood glucose level, of rats administered $125 \mathrm{mg} / \mathrm{kg}$ body weight of the extract, decline in the fasting blood glucose concentration began on day 3 and continued till day 6. Whereas, continuous reduction was recorded for fasting blood glucose concentration from day 2 upon oral administration of $250 \mathrm{mg} / \mathrm{kg}$ and $500 \mathrm{mg} / \mathrm{kg}$ body weight of the extract and standard drug (metformin).

\subsection{Effects of ethanolic extract of Acacia ataxacantha bark on hepatic glucose and glycogen concentration}

Figures 4 and 5 depict the effects of ethanolic extract of Acacia ataxacantha bark on the hepatic glucose and glycogen levels of STZ - induced diabetic rats. There was a significant difference $(p>0.05)$ in the hepatic glucose and glycogen levels in all the treatment groups compared to the normal control. However, highest hepatic glucose and least glycogen concentrations were recorded in the diabetic control when compared to the control.

\begin{tabular}{ll}
\hline Phytochemicals & Extract \\
\hline Alkaloids & + \\
Polyphenols & + \\
Flavonoids & + \\
Saponin & + \\
Glycoside & - \\
Tannins & + \\
Terpenoid & + \\
\hline
\end{tabular}

Keys: Presence of constituents (+); Absence of constituents (-)

Table 1. Phytochemical screening of ethanolic extract of Acacia ataxacantha bark 


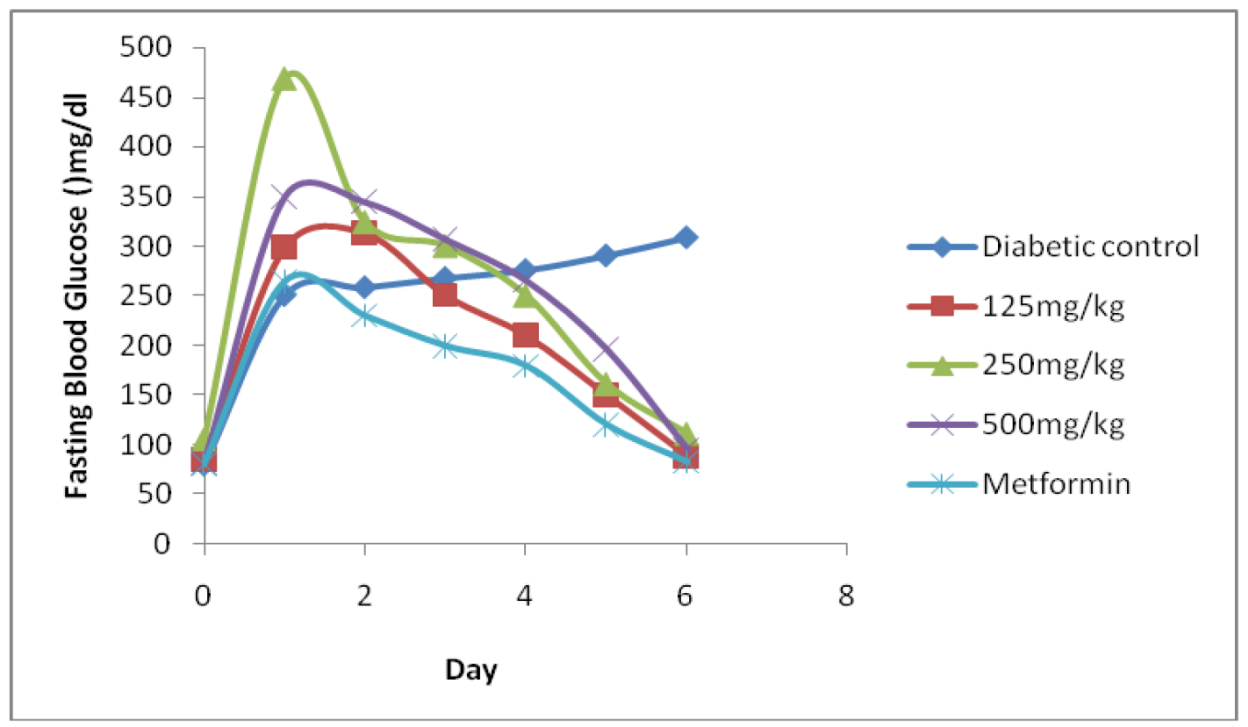

Figure 3. Effects of ethanolic extract of Acacia ataxacantha bark on the fasting blood level of STZ-induced diabetic rats

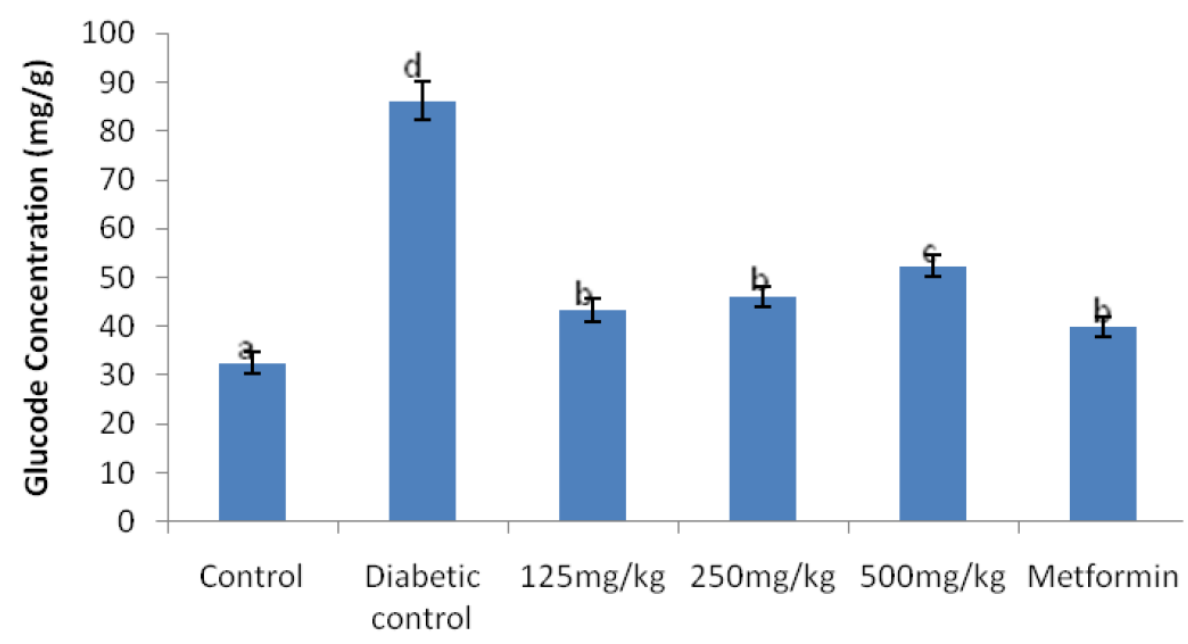

\section{Groups}

$\overline{\text { Values are means }}(n=6) \pm S . D$ (bars with different superscripts are significantly different at $p<0.05$ ).

Figure 4. Effects of ethanolic extract of Acacia ataxacantha bark on the hepatic glucose concentration of STZ-induced diabetic rats 


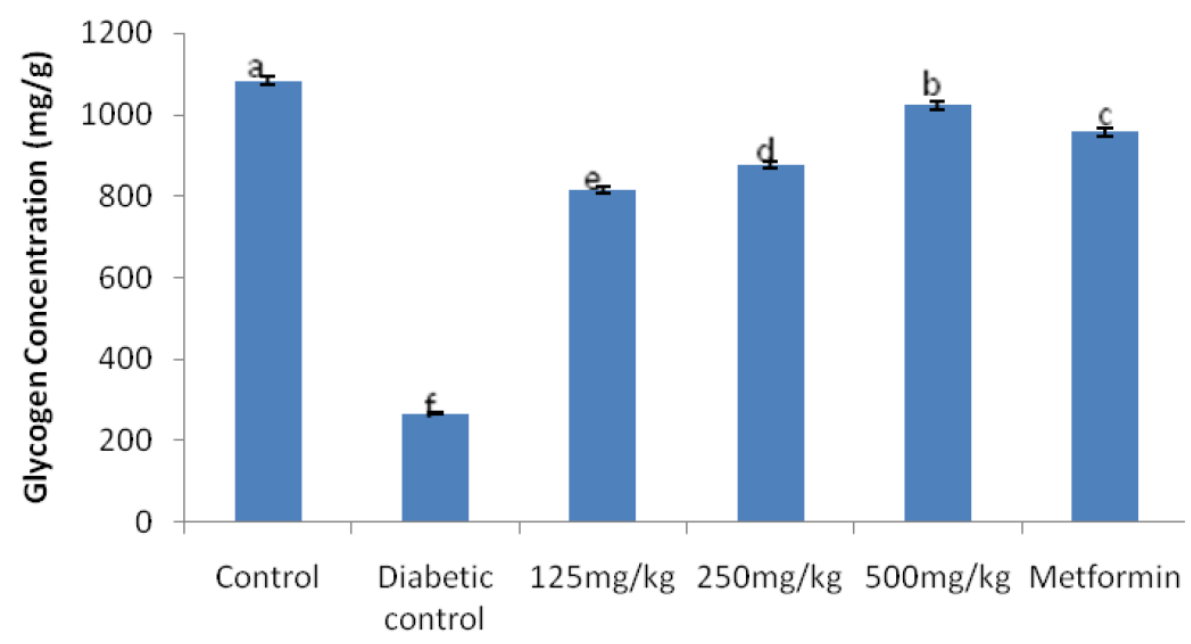

\section{Groups}

$\overline{\text { Values are means }}(n=6) \pm S . D$ (bars with different superscripts are significantly different at $p<0.05$ ).

Figure 5. Effects of ethanolic extract of Acacia ataxacantha bark on the hepatic glycogen concentration of STZ-induced diabetic rats

\subsection{Effect of administration of ethanolic extract of Acacia ataxacantha bark on serum parameters of streptozotocin-induced diabetic rats}

The influence of administration of ethanolic extract of Acacia ataxacantha bark on serum parameters is shown in Table 2. There was a significant difference $(p<0.05)$ in the urea level in all the treatment groups when compared to the control except that $250 \mathrm{mg} / \mathrm{kg}$ body weight and metformin displayed a similar pattern to the control. Also, there was no significant difference $(p>0.05)$ in the creatinine level in all the treatment groups when compared to the control but a significant increase $(\mathrm{p}<0.05)$ was observed in diabetic control compared to the normal control. There were significant differences $(\mathrm{p}<0.05)$ in albumin level of all groups compared to the control except that $250 \mathrm{mg} / \mathrm{kg} \mathrm{b.w} \mathrm{and} \mathrm{metformin} \mathrm{were} \mathrm{similar} \mathrm{in} \mathrm{pattern} \mathrm{to}$ the control.

\subsection{Effect of administration of ethanolic extract of Acacia ataxacantha bark on the lipids profile of streptozotocin-induced diabetic rats}

Figure 6 shows the effect of ethanolic extract of Acacia ataxacantha bark on serum total cholesterol (TC), high density lipoprotein cholesterol (HDL-C), low density lipoprotein cholesterol (LDL-C) and triglyceride. The serum total cholesterol (TC), low density lipoprotein cholesterol (LDL-C) and triglyceride concentrations were significantly reduced $(\mathrm{p}<0.05)$ upon administration of ethanolic extract of Acacia ataxacantha bark and metformin. 


\begin{tabular}{|c|c|c|c|c|c|c|}
\hline Parameters & Control & Diabetic control & $125 \mathrm{mg} / \mathrm{kg}$ & $250 \mathrm{mg} / \mathrm{kg}$ & $500 \mathrm{mg} / \mathrm{kg}$ & Metformin \\
\hline Urea & $29.67 \pm 0.3^{a}$ & $40.23 \pm 0.10^{c}$ & $23.49 \pm 1.19^{b}$ & $29.82 \pm 0.59^{a}$ & $21.04 \pm 1.22^{b}$ & $30.29 \pm 0.5^{a}$ \\
\hline Creatinine & $0.47 \pm 0.14^{\mathrm{a}}$ & $0.57 \pm 0.12^{b}$ & $0.48 \pm 0.15^{\mathrm{a}}$ & $0.48 \pm 0.01^{a}$ & $0.50 \pm 0.13^{a}$ & $0.49 \pm 0.10^{\mathrm{a}}$ \\
\hline Albumin & $18.67 \pm 0.33^{a}$ & $27.01 \pm 0.61^{c}$ & $22.00 \pm 1.15^{b}$ & $21.33 \pm 0.33^{c}$ & $25.33 \pm 0.88^{c}$ & $20.00 \pm 1.2^{\mathrm{ab}}$ \\
\hline
\end{tabular}

Values are expressed as mean of six determinations \pm SEM

Row values with different superscripts are significantly $(p<0.05)$ different

Table 2. Effects of ethanolic extract of Acacia ataxacantha bark on the concentration of some serum parameters of STZ-induced diabetic rats

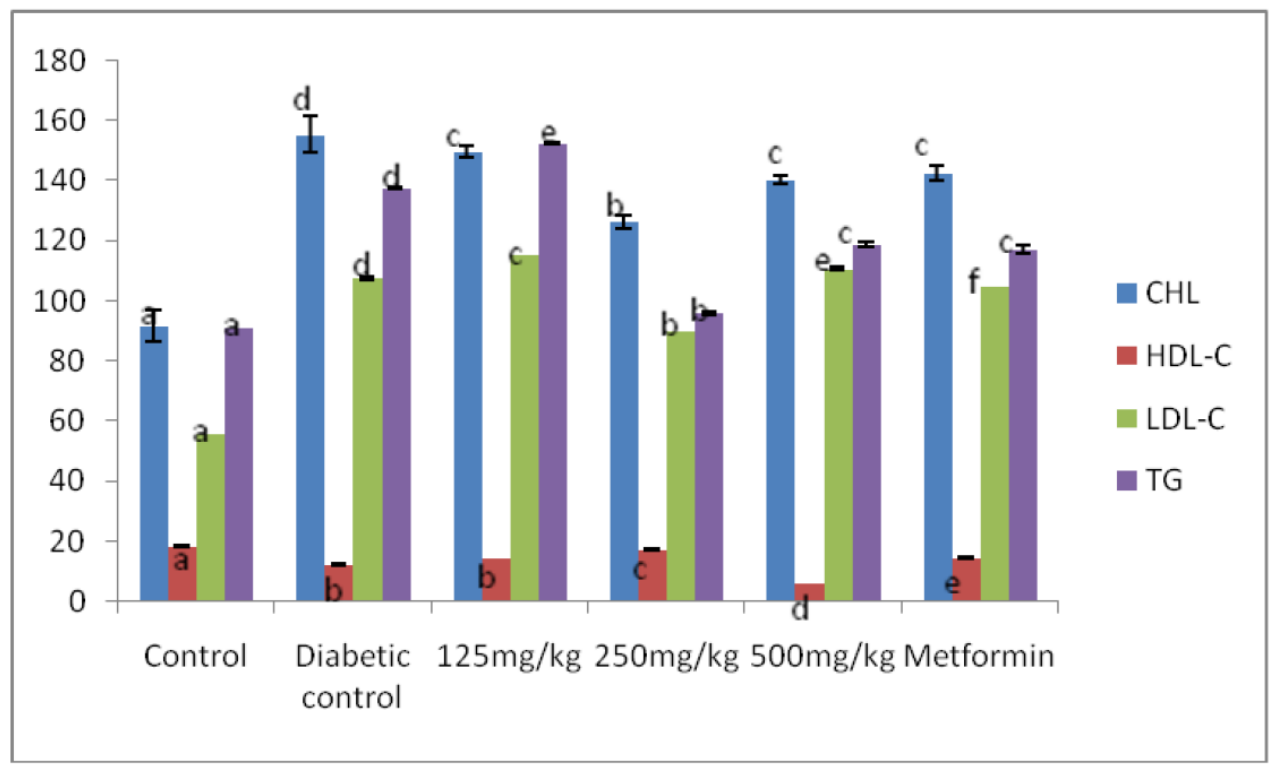

$\overline{\text { Values are means }}(n=6) \pm S . D$ (bars with different superscripts are significantly different at $p<0.05$ ).

Figure 6. Effects of ethanolic extract of Acacia ataxacantha bark on the serum lipid profile of STZ-induced diabetic rats

Figure 7 shows the effect of administration of ethanolic extract of Acacia ataxacantha bark on the total bilirubin and conjugated bilirubin level in streptozotocin induced diabetic rats. Both total biliribin and conjugated bilirubin were significantly higher $(\mathrm{p}<0.05)$ in diabetic untreated compared to the control, but it was significantly decreased $(\mathrm{p}<0.05)$ upon administration of ethanolic extract of Acacia ataxacantha bark and metformin. 


\subsection{Effect of the administration of ethanolic extract of Acacia ataxacantha bark on aspartate and alanine aminotransferase activities in streptozotocin induced diabetic rats}

Tables 3 and 4 show the effect of administration of ethanolic extract of Acacia ataxacantha bark on alanine and aspartate aminotransferase activities in the liver and serum respectively. There was a significant reduction $(\mathrm{p}<0.05)$ in the activity of ALT in the groups administered $500 \mathrm{mg} /$ $\mathrm{kg}$ b.w when compared to the control while there was no significant difference in the remaining treatment groups. However, in the serum, there was no significant difference $(p>0.05)$ in ALT activity except in the groups administered $500 \mathrm{mg} / \mathrm{kg}$ b.w and metformin when compared to the normal control. There were significant alterations $(p<0.05)$ in the activity of AST in the liver of all the groups compared to the normal control. However, significant elevations $(p<0.05)$ were observed in the activity of AST in the serum of all treatment groups when compared to the control.

\subsection{Effects of ethanolic extract of Acacia ataxacantha bark on pancreatic lipid peroxidation of streptozotocin-induced diabetic rats}

Figure 8 depicts the effects of ethanolic extract of Acacia ataxacantha bark on the pancreatic lipid peroxidation in STZ - induced diabetic rats. There were no significant differences $(p>0.05)$ in malondialdehyde concentration in the pancreas of rats administered $125 \mathrm{mg} / \mathrm{kg}$ body weight and metformin when compared to the control. However, there was a significant elevation $(\mathrm{p}<0.05)$ in the concentration of thiobarbituric acid (TBA) reacting substance in the pancreas of rats administered $250 \mathrm{mg} / \mathrm{kg}$ b.w, $500 \mathrm{mg} / \mathrm{kg}$ b.w and diabetic but not treated rats when compared to the normal control.

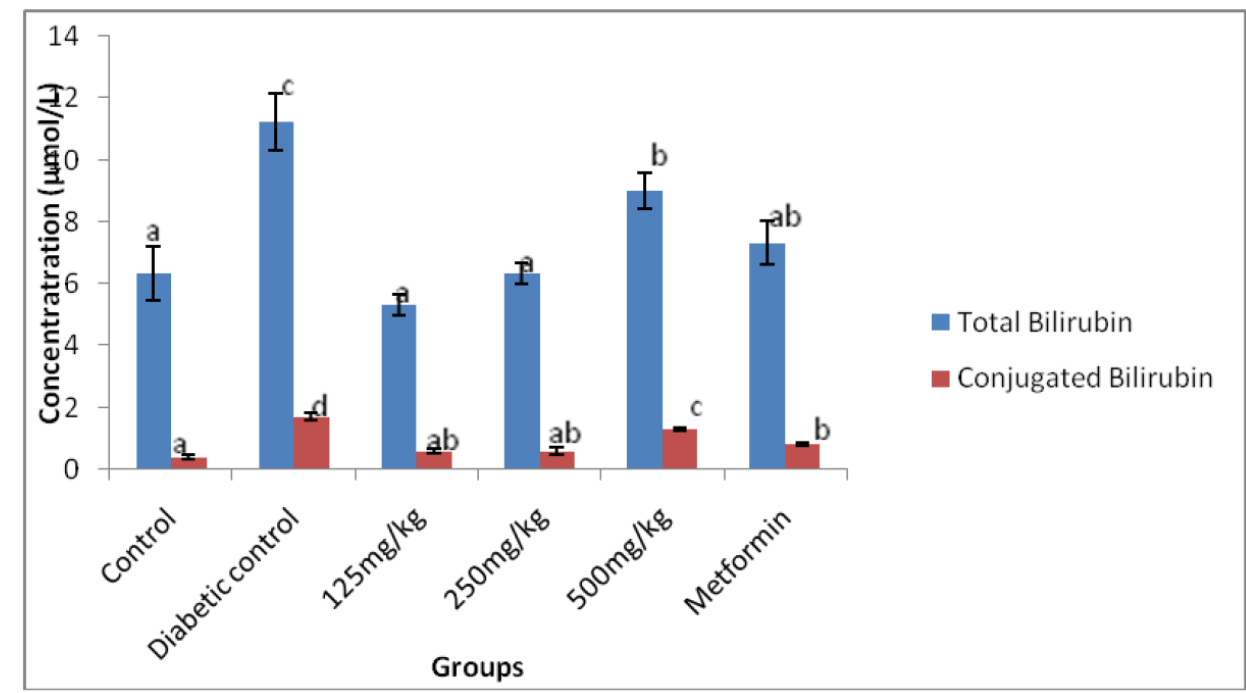

$\overline{\text { Values are means }}(n=6) \pm S . D$ (bars with different superscripts are significantly different at $p<0.05$ ).

Figure 7. Effects of ethanolic extract of Acacia ataxacantha bark on the bilirubin levels of STZ-induced diabetic rats 


\begin{tabular}{|c|c|c|c|c|c|c|}
\hline Parameters & Control & $\begin{array}{l}\text { Diabetic } \\
\text { control }\end{array}$ & $125 \mathrm{mg} / \mathrm{kg}$ & $250 \mathrm{mg} / \mathrm{kg}$ & $500 \mathrm{mg} / \mathrm{kg}$ & Metformin \\
\hline Liver & $0.48 \pm 0.00^{\mathrm{a}}$ & $0.14 \pm 0.00^{b}$ & $0.45 \pm 0.01^{\mathrm{a}}$ & $0.46 \pm 0.00^{a}$ & $0.14 \pm 0.00^{b}$ & $0.57 \pm 0.00^{\mathrm{a}}$ \\
\hline Serum & $0.15 \pm 0.01^{\mathrm{a}}$ & $0.46 \pm 0.00^{c}$ & $0.43 \pm 0.22^{b}$ & $0.17 \pm 0.00^{a}$ & $0.26 \pm 0.00^{b}$ & $0.15 \pm 0.20^{\mathrm{a}}$ \\
\hline
\end{tabular}

Values are expressed as mean of six determinations \pm SEM

Row values with different superscripts are significantly $(p<0.05)$ different

Table 3. Effect of the administration of ethanolic extract of Acacia ataxacantha bark on the alanine aminotransferase activities in streptozotocin-induced diabetic rats

\begin{tabular}{|c|c|c|c|c|c|c|}
\hline Parameters & Control & $\begin{array}{l}\text { Diabetic } \\
\text { control }\end{array}$ & $125 \mathrm{mg} / \mathrm{kg}$ & $250 \mathrm{mg} / \mathrm{kg}$ & $500 \mathrm{mg} / \mathrm{kg}$ & Metformin \\
\hline Liver & $0.36 \pm 0.03^{a}$ & $0.14 \pm 0.00^{b}$ & $0.68 \pm 0.00^{c}$ & $0.67 \pm 0.01^{c}$ & $0.13 \pm 0.02^{b}$ & $0.65 \pm 0.01^{c}$ \\
\hline Serum & $0.24 \pm 0.08^{a}$ & $0.72 \pm 0.01^{d}$ & $0.48 \pm 0.00^{b}$ & $0.62 \pm 0.00^{c}$ & $0.60 \pm 0.01^{c}$ & $0.52 \pm 0.01^{b}$ \\
\hline
\end{tabular}

Values are expressed as mean of six determinations \pm SEM

Row values with different superscripts are significantly $(p<0.05)$ different.

Table 4. Effect of the administration of ethanolic extract of Acacia ataxacantha bark on aspartate aminotransferase activity in streptozotocin-induced diabetic rats

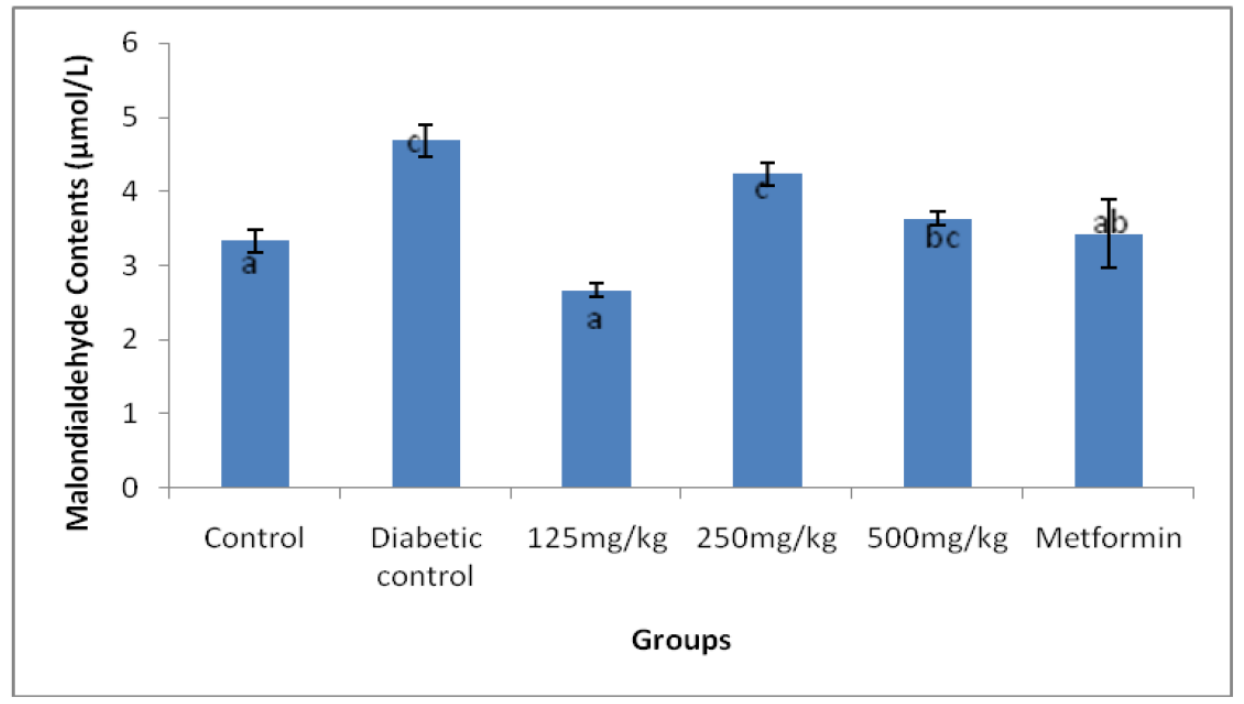

$\overline{\text { Values are means }}(n=6) \pm$ S.D (bars with different superscripts are significantly different at $p<0.05$ )

Figure 8. Effects of ethanolic extract of Acacia ataxacantha bark on the lipid peroxidation in STZ-induced diabetic rats 


\subsection{Effects of ethanolic extract of Acacia ataxacantha bark on pancreatic superoxide dismutase activities of streptozotocin-induced diabetic rats}

Figure 9 shows the effects of ethanolic extract of Acacia ataxacantha bark on the activity of pancreatic superoxide dismutase. There were significant alterations $(\mathrm{p}<0.05)$ in the superoxide dismutase activity in the pancreas of all the tretment groups except the groups administered $500 \mathrm{mg} / \mathrm{kg}$ b.w of the extract and metformin, which compared favourably with the control.

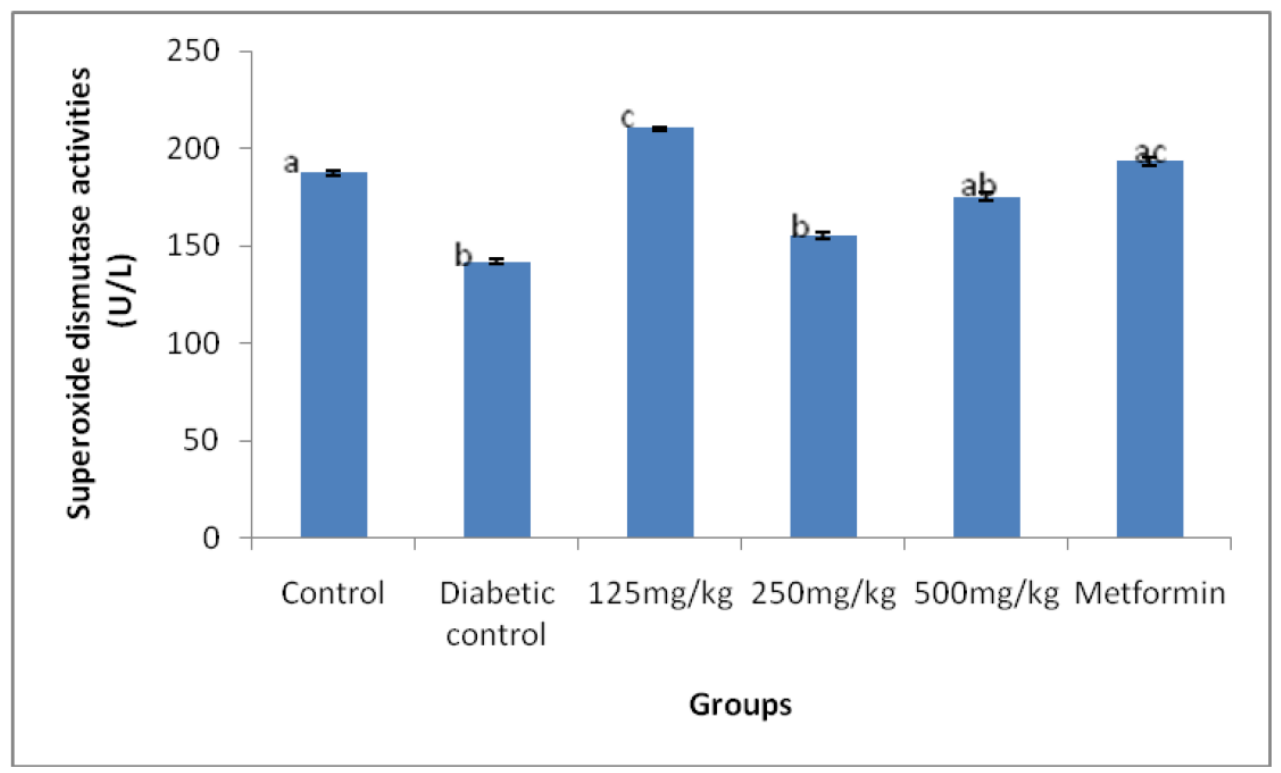

$\overline{\text { Values are means }}(n=6) \pm$ S.D (bars with different superscripts are significantly different at $p<0.05$ ).

Figure 9. Effects of ethanolic extract of Acacia ataxacantha bark on the superoxide dismutase activity of STZ-induced diabetic rats

\section{Discussion}

Diabetes mellitus is a metabolic disorder that has arguably achieved epidemic proportions. It is known to affect more than 371 million persons globally, and is projected to affect 522 million people by the year 2030 [1, 2 and 11]. Phytotherapy for some decades has played an important role in the management of the disease especially in resource-poor countries. Clearly, the identification of plant materials that can manage diabetes and its complications would save millions of people, especially in developing countries, from untimely death.

The presence of secondary metabolites such as alkaloids, polyphenols, flavonoid, saponins, tannins, and terpenoid in the ethanolic extract of Acacia ataxacantha bark may contribute to its 
hypoglyceamic activity and medicinal value. These compounds have been shown to be responsible for hypoglyceamic activity in Momordica charantia [37]. The activities of flavonoids and polyphenol have been ascribed to the structural relationship between different parts of their chemical structures [38].

STZ is a broad spectrum antibiotic extracted from Streptomyces acromogenes. The STZ-induced diabetes causes the destruction of pancreatic $\beta$ cells of islets, which leads to a reduction of insulin release and increase in blood glucose. STZ - induced diabetes has been described as a useful experimental model to study the antidiabetic activity of several agents [39]. STZ is well known for its selective pancreatic islet $\beta$-cell cytotoxicity used to induce diabetes mellitus in animals. It interferes with cellular metabolic oxidative mechanisms [39]. Significant elevation was observed in fasting blood glucose in diabetic rats. This observed hyperglycemia may be due to induced gluconeogenesis in the absence of insulin [40]. However, marked reductions observed after 2 days and the progressive decrease till the $6^{\text {th }}$ day which was highest in 125 $\mathrm{mg} / \mathrm{kg}$ and $250 \mathrm{mg} / \mathrm{kg}$ b.w of the extract compared well with the standard drug (metformin). These decreases could be due to the direct stimulation of the secretion of insulin thus promoting glucose uptake metabolism by inhibiting hepatic gluconeogenesis through the stimulation of a regeneration process and revitalization of the remaining beta cells [41].

The increased levels of hepatic glucose in streptozotocin - induced diabetic rats were reduced following the administration of ethanolic extract of Acacia ataxacantha bark. The reduced glucose levels suggests that ethanolic extract of Acacia ataxacantha bark may have exerted insulin-like effect on peripheral tissues by either promoting glucose uptake metabolism by inhibiting hepatic gluconeogenesis [42] or by absorption of glucose into the muscle and adipose tissues [43] through the stimulation of a regeneration process and revitalization of the remaining beta cells $[42,43]$.

Glycogen is the primary intracellular storable form of glucose in various tissues and its level in such tissues especially the liver is a direct reflection of insulin activity [44]. The glycogen content was decreased in the liver of diabetic rats in this study. But upon oral administration of ethanolic extract of Acacia ataxacantha bark, glycogen content were increased significantly which is comparable to that of metformin, thus confirming its insulin potentiating action to a marked extent. This may be due to the activation of glycogen synthase system and inhibition of glycogen phosphorylase [45] by the extract. It may also be due to decreased enzymatic activities of hexokinase and phosphofructokinase resulting in depletion of liver and muscle glycogen [46].

The concentrations of total protein, bilirubin and albumin may indicate state of the liver and type of damage [47]. Bilirubin is formed by the breakdown of hemoglobin in the liver, spleen and bone marrow [48]. An increase in tissue or serum albumin concentrations results in jaundice. Jaundice occurs in toxic or infectious diseases of the liver [49]. The significant increase in the total bilirubin, conjugated bilirubin and albumin levels in the diabetic control rats and reduction following oral administration of ethanolic extract of Acacia ataxacantha bark are indicative of amelioration of the adverse effects caused by diabetes. 
The kidneys remove metabolic wastes such as urea, uric acid, creatinine and ions and thus optimum chemical composition of body fluids is maintained. The concentrations of these metabolites increase in blood during renal diseases or renal damage associated with uncontrolled diabetes mellitus. Blood urea and creatinine are considered as significant markers of renal dysfunction [50]. Observed increase in urea and creatinine level in the diabetic control were reduced following the administration of ethanolic extract of Acacia ataxacantha bark to a level close to the value obtained for the normal control. Due to continuous catabolism of amino acid during diabetic state, high quantity of urea will be formed from urea cycle. On the other hand, it may be as a result of repression of glycolytic enzymes, thus glucose is channeled into pentose phosphate pathway resulting in the increased availability of ribose-5-phosphate which may lead to increased formation of phosphoribosyl pyrophosphate (PRPP) and ultimately resulting in high concentration of uric acid in the blood [51].

Lipids play a vital role in the pathogenesis of diabetic mellitus. Diabetic is associated with profound alterations in the plasma lipid, triglycerides and lipoprotein profile and with an increased risk of coronary heart disease [52]. The most common lipid abnormalities in diabetes are hypertriglyceridemia and hypercholesterolemia. The increase in the levels of serum lipids such as cholesterol and triglycerides in the diabetic rats may be due to the fact that under normal circumstances, insulin activates lipoprotein lipase and hydrolyses triglycerides. Insulin increases uptake of fatty acids into adipose tissue and increases triglyceride synthesis. Moreover, insulin inhibits lipolysis. In case of insulin deficiency, lipolysis is not inhibited but an increased lipolysis which finally leads to hyperlipidemia. In diabetic condition, the concentration of serum free acids is elevated as a result of free fatty acid outflow from fat deposited, where the balance of the free fatty acid esterification-triglyceride lipolysis cycle is displaced in favour of lipolysis [53].

HDL is an anti-atherogenic lipoprotein. It transports cholesterol from peripheral tissues into the liver and thereby acts as a protective factor against coronary heart disease. The level of HDL-cholesterol slightly increased after administration of ethanolic extract of Acacia ataxacantha bark at $250 \mathrm{mg} / \mathrm{kg}$ and $500 \mathrm{mg} / \mathrm{kg} \mathrm{b.w}$. This might be due to increase in the activity of lecithin cholesterol acyl transferase (LCAT), which may contribute to the regulation of blood lipids [54]. Administration of ethanolic extract of Acacia ataxacantha bark lowered cholesterol level at all doses while $250 \mathrm{mg} / \mathrm{kg}$ and $500 \mathrm{mg} / \mathrm{kg}$ b.w were able to reduce triglycerides and LDLcholesterol levels. Significant lowering of total cholesterol, triglycerides, LDL-cholesterol and rise in HDL-cholesterol is a very desirable biochemical state for prevention of atherosclerosis and ischaemic conditions [55].

Liver is the vital organ of metabolism, detoxification, storage and excretion of xenobiotic and their metabolites [56]. Aspartate aminotransferase, alanine aminotransferase, albumin and bilirubin are considered as part of liver toxicity markers [57]. In streptozotocin-induced diabetic animals, change in the serum enzymes is directly related to change in the metabolic functions of aspartate aminotransferase, alanine aminotransferase, albumin and bilirubin [58, 59]. It has been reported that the increased aminotransferase activities under insulin deficiency [60] were responsible for the increased gluconeogenesis and ketogenesis during diabetic. Aspartate aminotransferase is an enzyme found mainly in the cell of the liver, heart, skeletal 
muscles, kidney, and pancreas and to a lesser amount in red blood cells. Its serum concentration is proportional to the amount of cellular leakage or damage and it is released into the serum in larger quantities when any one of these tissues is damaged and its increase is usually associated with heart attack or liver disease. While on the other hand, alanine aminotransferase is an enzyme found mainly in the liver and elevated levels in serum usually indicates liver damage [61]. The mechanism by which the serum aspartate and alanine aminotransferases are raised in diabetic untreated may involve increased liberation of these enzymes from tissues (mainly liver), owing to oxidative stress or the formation of advanced glycosylation end product [57]. The increase in the activities of these enzymes in serum of diabetic control might be induced due to liver dysfunction. Ohaeri [62] reported that liver was necrotized in STZinduced diabetic rats. Therefore an increase in the activities of ALT and AST in the serum might be mainly due to the leakage of these enzymes from the liver cytosol into the blood stream [63] which gives an indication of hepatotoxic effect of STZ. Reduction in the activities of ALT and AST in the serum might consequently be due to alleviation of liver damage caused by STZinduced diabetic mellitus [64], while $500 \mathrm{mg} / \mathrm{kg}$ body weight might be toxic.

Malondialdehyde is used as a biomarker to measure level of oxidative stress in an organism [65]. Malondialdehyde participate in a variety of chemical and biological reactions including covalent binding to protein, RNA, and DNA. The significant increase $(p<0.05)$ in pancreatic malondialdehyde concentration in the diabetic but treated groups was reduced upon oral administration of the ethanolic extract of Acacia ataxacantha bark. These may be due to the presence of antioxidant phytochemicals in the extract which reduced the oxidative stress that caused lipid peroxidation thereby reducing the generation of free radicals and thus may have prevented the damage of cellular organelles either by decreasing localized oxygen concentration, presenting first chain initiation by scavenging initial radicals and binding metals or by decomposing peroxide. Antioxidant enzymes have been shown to play important role in maintaining physiological levels of oxygen and hydrogen peroxide by hastening the dismutation of oxygen radicals and eliminating organic peroxide and hydro-peroxides generated from inadvertent exposure to STZ [66]. In the enzymatic antioxidant defense system, SOD is one of the important enzymes that scavenge the superoxide radicals by converting them to hydrogen peroxides and molecular oxygen [67]. The observed decrease in the pancreatic SOD activity in diabetic control rats could result from inactivation by $\mathrm{H}_{2} \mathrm{O}_{2}$ or by glycosylation of the enzymes, which has been reported to occur in diabetes [68, 69]. However, the increased SOD activity following oral administration of ethanolic extract of Acacia ataxacantha bark might be due to presence of antioxidant phytochemicals which scavenge the superoxide radical by converting them to hydrogen peroxides and molecular oxygen [67].

\section{Conlusion}

Overall, it may be concluded that ethanolic extract of Acacia ataxacantha bark at $125 \mathrm{mg} / \mathrm{kg}$ b.w exhibited promising antidiabetic activity in streptozotocin-induced diabetic rats. Thus, the antihyperglyceamic and anti-dyslipidemic activity of ethanolic extract of Acacia ataxacantha bark could represent a protective mechanism against the development of atherosclerosis, 
especially in diabetic condition and may prove to be of clinical importance in the management of type 2 diabetes. However, this may not be safe at higher doses.

\section{Author details}

Rotimi O. Arise ${ }^{1^{*}}$, Aderounmu I. Ganiyu ${ }^{1}$ and Oluwafemi O. Oguntibeju ${ }^{2}$

*Address all correspondence to: arisedshine@yahoo.com

1 Department of Biochemistry, Faculty of Science, University of Ilorin, Ilorin, Nigeria

2 Department of Biomedical Sciences, Faculty of Health \& Wellness Sciences, Cape Peninsula University of Technology, South Africa

\section{References}

[1] Basu, S., Yoffe, P., Hills, N and Lustig, R.H (2013). The Relationship of Sugar to Population- Level Diabetes Prevalence: An Econometric Analysis of Repeated Cross-Sectional Data. PLoS ONE 8(2): e57873.

[2] Oputa, R.N and Chinenye, S. (2012). Diabetes mellitus: A global epidemic with potential solution. African Journal of Diabetes Medicine 20(2); 33-35.

[3] Wild, S.G., Roglie, A., Green, R., Sicree, E., King, H. (2004). Global prevalence of diabetes. Estimates for the year 2000 and projections for 2030. Diabet. Care, 27: 1047-1054

[4] Barcelo, A and Rajpathak, S. (2001). Incidence and prevalence of diabetes mellitus in the Americas. American Journal of Public Health, 10: 300-308

[5] Pari, L and Venkateswaran, S. (2003). Effect of an aqueous extract of Phaseolus vulgaris on the properties of tail tendon collagen of rats with streptozotocin-induced diabetes. Brazilian Journal of Medical and Biological Research, 36: 861-870

[6] Worthley, L.I.G. (2003).The Australian short course on intensive care medicine, Handbook, Gillingham printers, South Australia, PP 31-55

[7] Sowka, J. W., Gurwood, A. S. and Kabat, A. G. (2001). Handbook of ocular disease management diabetes mellitus. (http://www.revoptom.com/HANDBOOK/ sect59a.htm)

[8] Holt, R. I. G. (2004). Diagnosis, epidemiology and pathogenesis of diabetes mellitus: an update for psychiatrists. British journal of Psychiatry, 184 (suppl.4 7), s 55- s 63 
[9] Tiwari, A. K. and Rao, J. M. (2002). Diabetes mellitus and multiple therapeutic approaches of phytochemicals: Present status and future prospects. Current Science, 83: 30-38

[10] Trachtenbarg, D. E. (2005). Diabetic ketoacidosis. American Family Physician, 71: 17051714

[11] International Diabetes Federation (2011). Diabetes Atlas: 5th Edition.

[12] Grover, J.K., Yadar, S. and Vats, V. (2002). Medicinal plants of India with anti-diabetic potential J. Ethnopharmacol. ; 81: 81-100.

[13] Rang H.P. and Dale M.M., (1991).The Endocrine System Pharmacology, (Longman, Harlow) 504.

[14] Bastaki, S. (2005). Diabetes mellitus and its treatment. Int. J. Diabetes and Metabolism. 13: 111-134.

[15] Kofi, N., Edouard, K.K and Kouassi, K (2009). Ethnobotanical Study of Plants Used to Treat Diabetes, in Traditional Medicine, by Abbey and Krobou People of Agboville (Côte- d'Ivoire) Am. J. Sci. Res. 4: 45-58.

[16] Oyedemi, S.O, Yakubu, M.T and Afolayan, A.J. (2011). Antidiabetic activities of aqueous leaves extract of Leonotis leonurus in streptozotocin induced diabetic Rats. Journal of Medicinal Plants Research, 5(1):119-125.

[17] Pari, L. and Uma Maheswari, J. (2000). Antihyperglycemic activity of Musa sapientum flowers. Effects on lipid peroxidation in alloxan diabetic rats. J. Ethnopharmacol., 14, $1-3$

[18] Grover, J.K., Yadav, S. and Vats V. (2002). Medicinal plants of Indian with antidiabetic potential. J. Ethnopharmacol., 81, 81-100.

[19] Davidson, L and Jeppe, B (1981). Acacias: A field guide to the Acacias of southern Africa. 1st ed. Johannesburg: Centaur, Johannesburg.

[20] Derelanko M.J. Guiding Principles in the use of Animals in Toxicology In: Toxicologist's pocket handbook. CRC Press Boca Raton, London.2000; pp 1-7.

[21] Majekodunmi OF, Zany I, Ohanyaga IE, Shi LE, Mclanghin JL, (1996).Selective cytotoxic diterpene from Euphorbia poisonic. J. Med.Chem., 39: 1005-1008

[22] Sekar N, Kanthasamy S, William S, Subramanian S, Govindasamy S. Insulinic actions of vanadate in diabetic rats. Pharmacol Res 1990; 22:207-17.

[23] Ogbu SI, Okechukwu EI (2001). The effect of storage temperature prior to separation on plasma and serum potassium. J.Med. Lab. Sci., 10:1-4.

[24] Ngaha EO, Akanji MA, Madusolomo MA (1989). Studies on correlation between chloroquine-induced tissue damage and serum changes in rats. Experimentia, 45: 143. 
[25] Barham, D. and P. Trinder, (1972). An improved colour reagent for the determination of blood glucose by the oxidase system. The Analyst, 97:142-145.

[26] Passonneau J. V. and Lauderdale V. R. (1974) A comparison of three methods of glycogen measurement in tissues. Anal. Biochem. 60, 405-412

[27] Reitman, S. and Frankel, S. (1957). A colourimetric method for determination of serum glutamate-oxaloacetate and pyruvate transaminase. Am. J. Clinpath. 28:56-59. Research Service, 25-30.

[28] Zlakis, A., B. Zak and A.Boyle, (1953). A new method for the direct determination of serum cholesterol. J Lab. Clin. Medic., 4: 486-492.

[29] Foster C.S, Dunn O (1973). Stable reagents for determination of serum triglycerides by a colorimetric Hantzsch condensation method. Clin Chim Acta, 19, 338-340.

[30] Burstein, M., Scholnick, H. R. and Morfin, R. (1970) Rapid method for the isolation of lipoproteins from human serum by precipitation with polyanions. J. Lipid Res. 11, 583-595.

[31] Friedewald, W.T., Levi, R.I., Fredrickson, D.S. (1972). Estimation of the Concentration of Low-Density Lipoprotein Cholesterol in Plasma, Without Use of the Preparative Ultracentrifuge Clin. Chem., 18: 499.

[32] Doumas, B.T., Watson, W.A., Biggs, H.G. (1971). Albumin standards and measurement of serum albumin with bromocresol green. Clin. Chim. Acta. 31: 87-92.

[33] Sherlock, S. (1951). In Liver Disease. Chuchill London. p. 204.

[34] Tietz, N.W., Prude, E.L. and Sirgard- Anderson, O (1994). Tietz Textbook of clinical chemistry. 2nd edition,W.B. Saunders Company, London, pp. 1354-1374.

[35] Misra, H.P. and Fridovich, I. (1972). The role of superoxide anion in the autooxidation of epinephrine and a simple assay for superoxide dismutase. J Biol chem. 247: 3170-3175.

[36] Varshey, R., Kale, R.K. (1990). Effect of calmodulin antagonist on radiation induced lipid peroxidation in microsome. Int. J. Rad. Biol. 58, 733-743.

[37] Akhtar, M.S., Athar, M.A and Yaqub, M. (1981). Effect of Momordica charantia on blood glucose level of normal and alloxan-diabetic rabbits. Planta Med., 42: 205-212.

[38] Rice-Evans, C., Miller, N.J and Paganga, G. (1996). Structure-antioxidant activity relationship of flavonoids and phenolic acids. Free Radical Biology and Medicine, 20:933956.

[39] Papaccio, G., Eposito, V., Latronico, M.V and Pisanti, F.A.(1995). Administration of a nitric oxide synthase inhibitor does not suppress low-dose streptozotocin-induced diabetes in mice. Int.J. Pancreatol. 17:63-68. 
[40] Gao Z, Hwang D, Bataille F, Lefevre M, York D, Quon MJ, Ye J. 2002. Serine phosphorylation of insulin receptor substrate 1 by inhibitor kappa B kinase complex. J. Biol. Chem. 277: 48115-48121.

[41] Rokeya, B. (1993): Studies on the hypoglycemic effects of fruits pulp, seed and whole plant of Momordica charantia on normal and diabetic model rats, Planta Med. 59: 408-412.

[42] Ali, L., Azad Khan, A. K., Mamun, M.I.R., Mosihuzzaman, M., Nahar, N., Alan, M.N.E. Anderson, O.M. and Markham, K.R. (2006). Flavonoids: Chemistry, Biochemistry and Applications. CRC Press.

[43] Kamanyi, A., Dajmen, D. and Nkeh, B. (1994): Hypoglycemic properties of the aqueous root extract of Morinda lucida (Rubiacea) study in the mouse, Phytoter Res. 8: 369-371.

[44] Sharma, A.K. (1993). Diabetes mellitus and its complications: An update, 1ed. Macmillan India Ltd, New Delhi: Sharma AK (ed), pp 92- 205.

[45] Bansal, R., Ahmad, N and Kidwai, J.R. (1981). Effect of oral administration of Eugenia jambolana seeds and chloropropamide on blood glucose level and pancreatic cathepsin B in rats, Indian J. Biochem. Biophys. 18: 377-381.

[46] Grover, J.K., Vats, V. and Rathi, S.S. (2000). Antihyperglycemic effect of Eugenia jambolana and Tinospora cordifolia in experimental diabetes and their effects on key metabolic enzymes involved in carbohydrate metabolism. J. Ethnopharmacol. 73: 461-470.

[47] Yakubu, M.T., Akanji, M.A. and Oladiji, A.T. (2005). Aphrodisiac potentials of the aqueous extract of Fadogia agrestis (Schweinf. Ex Heirn) stem in male albino rats. Asian J. Androl. 7: 399-404.

[48] Vasudevan, D.M. and S. Sreekumari, (2005). Textbook of Biochemistry (For Medical Students). 4th Edn., Jaypee Brothers Medical Publishers (P) Ltd., New Delhi, India, pp: 502-503.

[49] Edem, D.O. and Usoh, I.F. (2009). Biochemical Changes in Wistar Rats on Oral Doses of Mistletoe (Loranthus micranthus). American Journal of Pharmacology and Toxicology, 4 (3):94-97.

[50] Almdal, T.P, Vilstrup, H. (1988). Strict insulin treat-ment normalizes the organic nitrogen contents and the capacity of urea-N synthesis in experimental diabetes in rats. Diabetologia; 31:114-118.

[51] Lal, S.S., Sukla, Y., Singh, U. (1991). Treating insulin resistance in hypertension with metformin reduces both blood pressure and metabolic risk factors. J. Intern. Med. 229:181-187. 
[52] Maghrain, M. Lemhadri, A., Zeggwagh, N. A., El-Amraoui, M., Haloui, M., Jouad, H. and Eddouks, M. (2004): Effects of an aqueos extract of Triticum repens on lipid metabolism in normal and recent-onset diabetic rats. J. Ethnopharmacol. 90:331-336.

[53] Sirwalkar, A., Rajendran, K., Kumar, C.D. and Bodla, R. (2004): Antidiabetic activities of aqueous leaf extract of Annona squamosa in streptozotocin-nicotonamide type 2 diabetic rats. J. Ethnopharmacol. 91: 171-175.

[54] Patil, U. K., Saraf, S. and Dixit, V.K. (2004): Hypolipidemic activity of seeds of Cassia tora Linn. J. Ethnopharmacol. 90:249-252.

[55] Luc, G. and Fruchart, J.C. (1991): Oxidation of lipoproteins and atherosclerosis. American Journal of Clinial Nutrition 53: 2065-2095.

[56] Rej, R. (1978): Aspartate aminotransferase activity and isoenzymes proportions in human liver tissues, Clin. Chem. 24 (11): 1971-1979.

[57] Mori, d. M., Baviera, A.M., Ramallo, L.T.D.O., Vendramini, R.C., Brunetti, I. L. and Pepato, M.T. (2003): Temporal response pattern of biochemical analytes in experimental diabetes, Biotechnol. Appl. Biochem. 38, 183-191.

[58] Asayama, K., Nakane, T., Uchida, N., Hayashihe, H., Dobashi, K., Nakazawa, S. (1994); Serum antioxidant status in streptozotocin-induced diabetic rat. Horm. Metab. Res. 26: 313- 315.

[59] Junad, A., Lambery, a. e., Orci, L., Pictet, R., Gonet, A.E. and Ronald, A.E. (1967): Studies of diabetogenic action of streptozotocin. Proc. Soc. Exp. Biol. Med. 126:201-205.

[60] Fleig, P., Marliss, E., Ohman, J. and Cahill, J. F. (1970): Plasma amino acid levels in diabetic keto acidosis. Diabetes 19: 727-729.

[61] Kesari, A.N., Kesari, S., Singh, S. K., Gupta, R.K. and Watal, G. (2007): Studies on the glycemic and lipidemic effect of Murraya koenigii in experimental animals. J. Ethnopharmacol. 112:305-311.

[62] Ohaeri, O.C. (2001): Effect of garlic oil on the levels of various enzymes in the serum and tissue of streptozotocin diabetic rats, Biosci. Rep. 21:19-24.

[63] Navarro, C.M., Montilla, P.M., Martin, A., Jimenez, J. and Utrilla, P. M. (1993): Free radical scanvenger and antihepatotoxic activity of Rosmarinus, Plant Med. 59:312-314.

[64] El-demerdash, F.M., Yousef, M. I. and Abou El-Naga N. I. (2005): Biochemical study on the hypoglycemic effects of onion and garlic in alloxan-induced diabetic rats, Food Chem. Toxicol. 43: 57-63.

[65] Moore, K.L. and Dalley, A.F. (1999). Clinical Oriented Anatomy (4 ${ }^{\text {th }}$ Edition). Lippincot Williams and Williams; a Woller klumner Corporation, Philadelphia. pp. 263-271. 
[66] Pari, L. and Uma Maheswari, J. (2000). Antihyperglycemic activity of Musa sapientum flowers. Effects on lipid peroxidation in alloxan diabetic rats. J. Ethnopharmacol., 14, 1-3 67.

[67] Vincent, A.M., Russell, J.W., Low, P. and Feldman, E. L. (2004): Oxidative stress in the pathogenesis of diabetic neuropathy. Endocr Rev 25:612-628.

[68] Ravi, K., Ramanchandran, B and Subramanian, S. (2004): Protective effect of Eugenia jambolana seed kernel on tissue antioxidants in streptozotocin-induced diabetic rats. Biol Pharm Bull 27: 1212-1217.

[69] Soon, Y.Y. and Tan, B.K. (2002): Evaluation of the hypoglycemic and antioxidant activities of Morinda officinalis in streptozotocin-induced diabetic rats. Singapore Med J 3: 77-85 
